\title{
On the mechanisms of diabetogenic activity of Xanthurenic acid
}

\author{
Meyramov GG* and Meyramova-Abdraimova AG \\ Family Diabetes Research Group, Karaganda, Kazakhstan
}

Abbreviations: XA: Xanthurenic acid; DD8: diabetogenic derivatives of 8-oxyquinolin.

In 1935 Musajo L and coll reported about synthesis of Xanthurenic acid. This chemical was separated from urine of experimental animals and identified as 4,8-digidroxyquinolin-2-carboxylic acid (XA), a derivative of 8-oxyquinolin [1]. Formula: $\mathrm{C}_{10} \mathrm{H}_{7} \mathrm{NO}_{4}$.

Accumulation in organism of large amount of fatty acids and tryptophan in the deficiency of vit.B6 (pyridoxine) result intensive synthesis of XA in tissue. It was followed by developing in animal symptoms of diabetes [2-8].

This product interested by group of Lepkovsky S [2]. In the conditions of accumulation in orga- nism of contain on diet enriched by fatty acids and a tryptophan in the deficiency of vit.B6 (pyridoxine) there are a intensive endogene synthesis of XA that accompanied by developing of symptoms of diabetes in animals [3-8] and histological changes:vacuolisation of cytoplasm, gydropic distrophya, destruction of nuclei $[4,5]$. Kotake Y.noted a strong likeness of chemical structure of XA with other DD8 (Figure 1). He supposed that diabetogenic properties of XA maybe determined by $\mathrm{OH}^{-}$radical located in position "8" [10,11]. XA possess a high affinity for ions of Zinc [12]. We've fixed attention that XA as as well as other DD8 possess diabetogenic properties only in case if $\mathrm{OH}^{-}$radical is fixed in the position " 8 " of a quinolin ring (Figure 1). Kotake $\mathrm{Y}$ and Kato $\mathrm{M}$ showed that extraction or replacement of radical from position " 8 " accompanied by complete disappearing of diabetogenic properties of XA [13]. Weitzel G. confirmed [14] that XA forms with Zinc ions a chelate complex 1:1 and atom of Zinc is fixed between hydroxyl and carboxylic groups of a quinolinic ring. It is known that such type of complex of metal with derivatives 8-oxyquinolines is the most toxic for cells. Murakami E.showed that incubation of Xanthurenic acid with insulin result formation of two complexes that accompanied by decreasing of insulin activity for $50 \%[15,16]$. In one of them insulin is bound to 1 mole of Xanthurenic acid and in the second - with 1,5 mole. Xanthurenic acid easily formed complex with insulin in blood serum, without breaking structure of insulin. This complex is stable [17]. It was supposed that chemical connection is carried out between atom of Zinc and imidazole radical in a molecule of insulin [18]. Xanthurenic acid shows a high affinity for ions of Zinc [10]. Activity of insulin is restored after addition of ions of Zinc to blood serum contains of complex XA-insulin [18]. On the base of obtained results, Kotake Y., Ueda T. and coll [19] proposed a following me- chanisms of diabetogenic effect of Xanthurenic acid (Fig.2,left part).Meanwhile, Ueda T. and coll. found out that after dissociation of a complex XA-insulin a new complex as XA-Zinc is formed, however attention to this fact was not given and this ability was not investigated. In experiences of in vivo and in vitro it was showed that XA interact with Zinc in B-cells that accompanied by damage of cells [20-29].

On the base of results obtained by Kotake Y., Ueda T.in 1957-1975 reported that formation of complex "XA-insulin"result overstrain of B-cells and followed alteration of cells accompanied more later by developing of symptoms of diabetes (Figure 2).

In 1972 on the base of our previous results of investigation of mechanisms of diabetes caused by DD8 we have fixed attention on fact that on chemical structure of XA correspond to other DD8 too. But contrary to all other investigated DD8 XA is easy synthesized in animals and elderly human in conditions of deficiency of Pyridoxin (vit.B6) and food enriched by fats. Iit was showed that XA result binding of Zinc ions in B-cells and its destructionon [21,23,30]. In B-cells insulin formed deposited form with Zinc as storage complex Zinc-insulin. It was established that XA in B-cells interact with Zincions that accompanied by complete negative reaction for Zinc $[29,30]$ (Figure 3) that determined by formation of complex XA-Zinc. Zincatom is located between $\mathrm{OH}^{-}$-radical in position 8 as in toxic complexes 1:1 [14] of Zinc with other DD8 (Figure 1) and carboxyl group. It was established in added that disposition of maximal concentration of complexes zinc-DD8 in zones of contact with capillaries wall on B-cells result destruction of wall that as we suppose - result disturbances of blood circulation in islets and to aggravate alteration of B-cells [30]. On the base of all results obtained by Kotake Y. and of our results we propose a following mechanisms of diabetogenic properties of Xanthurenic acid (Figure 2) and of mechanisms of diabetogenic activity of diabetogenic derivatives of 8-oxyquinolin including XA (Figure 4).

Interest for diabetes induced by XA is increased due to followed factors:

1. XA in the contrary to other diabetogenic derivatives of 8-oxyquinolin is formed in human organism as result of simple changes of diet.

2. A large amount of XA is discovered in the urine not only of diabetic patients in middle or old age, but in the urine of persons in same age without diagnosis of diabetes.

3. Deficiency of vitamin B6 is discovered in organism of old persons with registrated diagnosis of diabetes or without it.

${ }^{\star}$ Correspondence to: Meyramov GG, Family Diabetes Research Group, Karaganda, Kazakhstan, E-mail: meyramow@mail.ru

Received: September 19, 2018; Accepted: October 01, 2018; Published: October 09,2018 


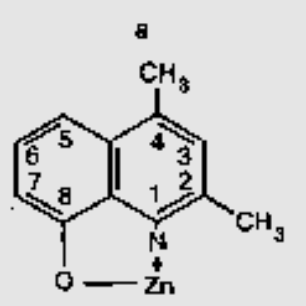

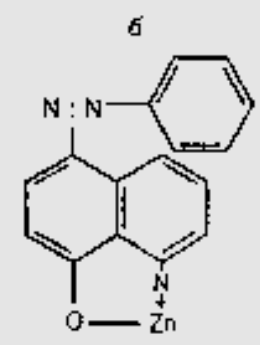<smiles>Cc1ccc(N=Nc2ccc3c4c2N(CC3)CC4)cc1</smiles><smiles>Cc1ccccc1N=Nc1ccc2c3c(cccc13)OCC2</smiles><smiles>c1cc2c3c(cccc3c1)[Te]O2</smiles>

e

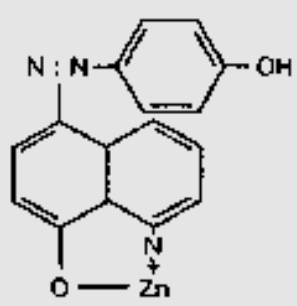<smiles>Oc1cccc(N=Nc2ccc3c4c(cccc24)NC[Z10]3)c1</smiles>

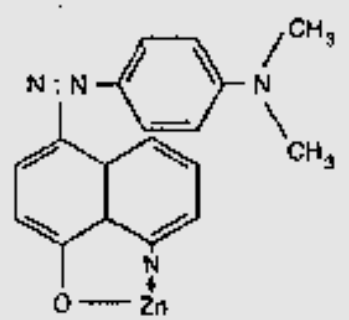<smiles>CC(=O)Nc1ccc(N=Nc2ccc3c4c2NC(C4)O3)cc1</smiles><smiles>Cc1ccc2cccc3o[Y20]c1c23</smiles>

$\pi$.<smiles>Nc1ccc(N=Nc2ccc3[Z6](=O)[nH]c4cccc2c43)cc1</smiles><smiles>Nc1ccc2c3c(cccc13)O[Te]2</smiles><smiles>CCCCCCN(CC)c1ccc(N=Nc2ccc3c4c(cccc24)NCC3)cc1</smiles><smiles>[Ga]Oc1cccc2ccccc12</smiles>

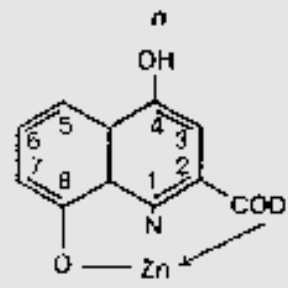

o

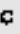

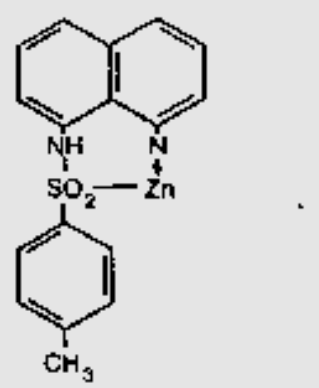<smiles>O=[W](Nc1cccc2ccccc12)c1ccccc1</smiles><smiles>C[AsH]c1cccc2cccc(N(C)C)c12</smiles><smiles></smiles>

Figure 1. Complex salts of DD8 with Zn-ions and its diabetogenic doses:

a) 2,4-dimethyl-8-oxyquinolin, $35 \mathrm{mg} / \mathrm{kg}$; б) 5-phenylaso-8-oxyquinolin, $20 \mathrm{mg} / \mathrm{kg}$; в) 5-para (toluene)-8-oxyquinolin, $20 \mathrm{mg} / \mathrm{kg}$; г) 5-orto- (toluene)-8-oxyquinolin, $40 \mathrm{mg} / \mathrm{kg}$; д) 8-0xyquinolin, $50-60 \mathrm{mg} / \mathrm{kg}$; e) 5-para (diethylaminophenylaso)-8oxyquinolin, $20 \mathrm{mg} / \mathrm{kg}$; ж) 5 -meta(hydroxyphenylaso)-8-oxyquinolin, $30 \mathrm{mg} / \mathrm{kg}$; 3) 5 -para(dimethylaminophenylaso)8-oxyquinolin, $45 \mathrm{mg} / \mathrm{kg}$; и) 5-para(acetylaminophenylaso)-8-oxyquinolin, $50 \mathrm{mg} / \mathrm{kg}$; к) 8-oxyquinaldin, $10 \mathrm{mg} / \mathrm{kg}$; л) 5-para (aminophenylaso)-8-oxyquinolin, $10 \mathrm{mg} / \mathrm{kg}$; м) 5-amino8-oxyquinolin, $30 \mathrm{mg} / \mathrm{kg}$; н) 5-para (diethylaminophenylaso)-8-oxyquinolin, $40 \mathrm{mg} / \mathrm{kg}$; o) 9-oxy-7-jodoquinolin, $50-60 \mathrm{mg} / \mathrm{kg}$; п) 4,8-dihydroxyquinolin-2 carboxylic acid (xantu- renic acid); p) 8-para (toluenesulphonylamino)quinolin, 30-50 mg/kg; c) 8-para( benzolsulphonylamino)quinolin, 30-100 mg/kg; т) 8-para (metansulphonylamino)quinolin, 40-81 mg/kg; y) diphenylthiocarbazone (dithizon), 45-50 mg/kg.(by Meyramova A.G.,2003) 


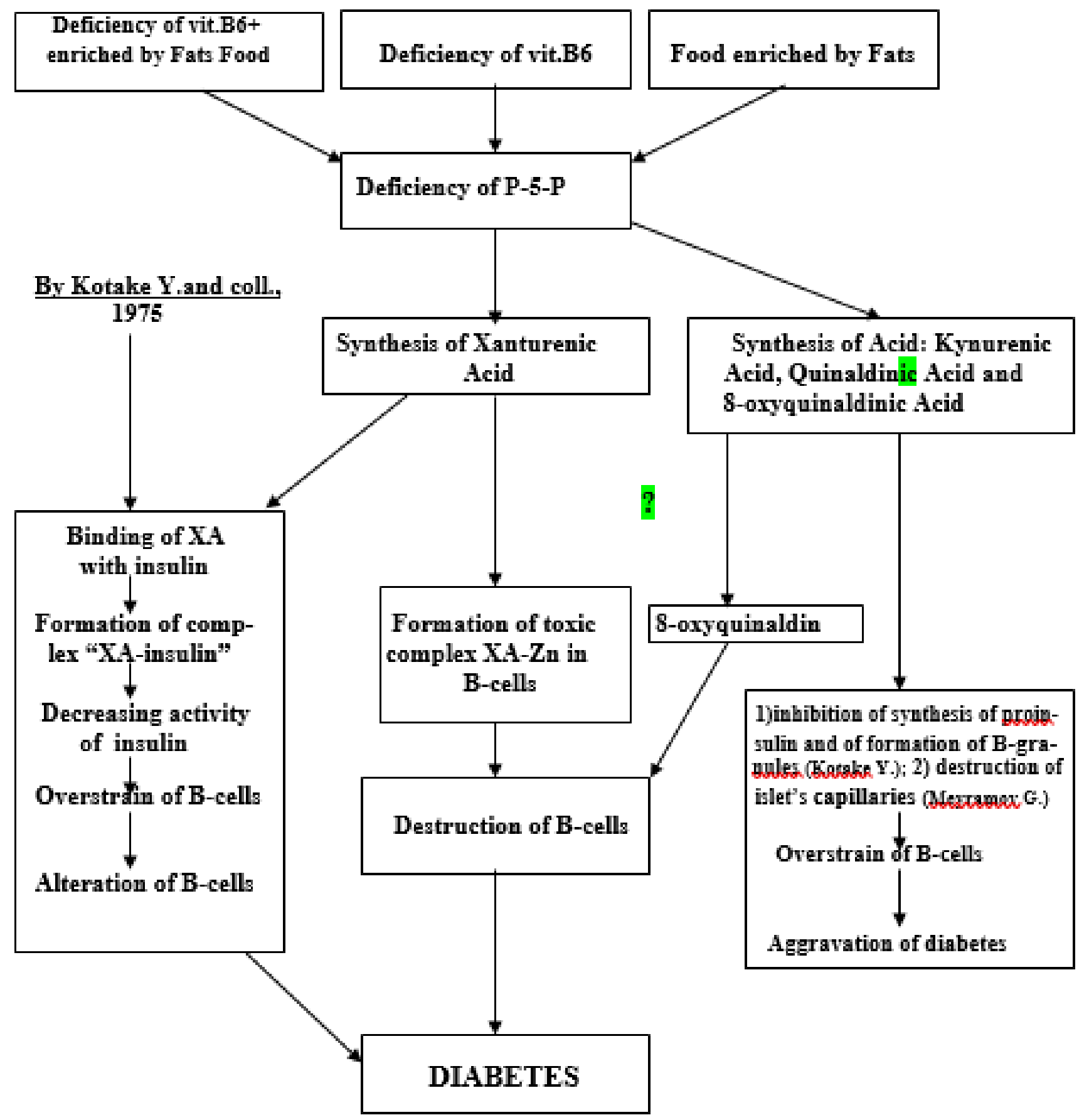

Figure 2. Mechanisms of diabetogenic activity of xanthurenic 

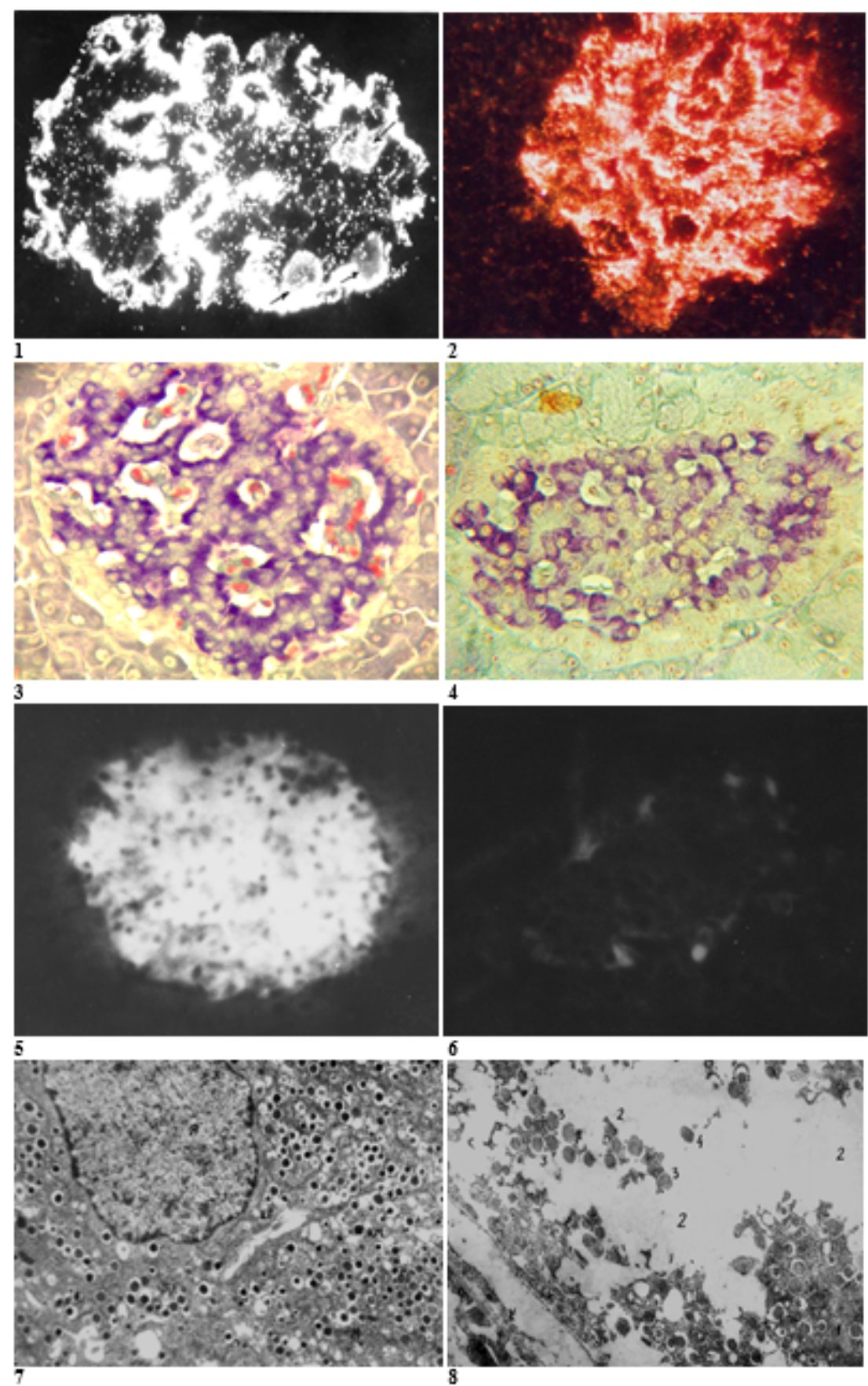

Figure 3. Histostructure and ultrastructure of pancreatic islets in animals with diabetes caused by zincbinding chemicals (ditizon and xanthurenic acid)

3.1. Intact Rabbit. Injection of Ditizon (DZ),31mg/kg.Granules of complex Zn-DZ concentrated around capillaries; frozen section, 4 mcm; darc condensor; $\mathrm{x} 280$; preparat and photo - by Meyramov GG 1964

3.2. Intact Rabbit. Injection of Ditizon (DZ), $50,6 \mathrm{mg} / \mathrm{kg}$. Large amount of granules of complex Zn-DZ in cytoplasm of B-cells; frozen section, $5 \mathrm{mcm}$; darc condensor; $\mathrm{x} 280$; preparat and color photo - by Meyramov GG 2012

3.3. Intact Rat. Aldehydefucshin.Maximal concentration of violet granules of zinc-insulin depot form of insulin in B-cells around capillaries; $\mathrm{x} 280$; preparat and photo -by Meyramov GG 2008

3.4. Rat with diabetes induced by endogen synthesized of XA. Aldehydefucshin. Destruction and degranulation of B-cells in central part of islet; x280; preparat and photo -by Meyramov GG 2001

3.5. Intact Rabbit. High specific fluorescent reaction with Zinc-ions using of fluorochrom as 8-para(toluene-sulpho-nylamino) quinolin. Intensive fluorescence of complex Zinc-fluorochrom in B-cells; frozen sections; x140; preparat and photo -by Meyramov GG 1978

3.6. Injection of XA, $195 \mathrm{mg} / \mathrm{kg}$; frozen section; darc condensor; $\mathrm{x} 140$ negative reaction for Zinc-ions; preparat and photo - by Meyramov GG 1993

3.7. Intact B-cell of Rabbit. Transmission electron microscopy. Cell matrix without changes; a large amount of B-granules in cytoplasm contains deposited form of insulin as Zinc-insulin complex; x4450; preparat and photo - by Meyramov GG 1973

3.8. B-cells of Rabbit $2 \mathrm{~h}$ past injection of Dithizon, $49,6 \mathrm{mg} / \mathrm{kg}$. Trans- mission electron microscopy; 1-destruction of cell matrix [on $80-90 \%$ of cell's surface]; 2 -zones of cytoplasm free of matrix; a few destroyed B-granules in zones free of matrix; x5650; preparat and photo - by Meyramov GG 1973 


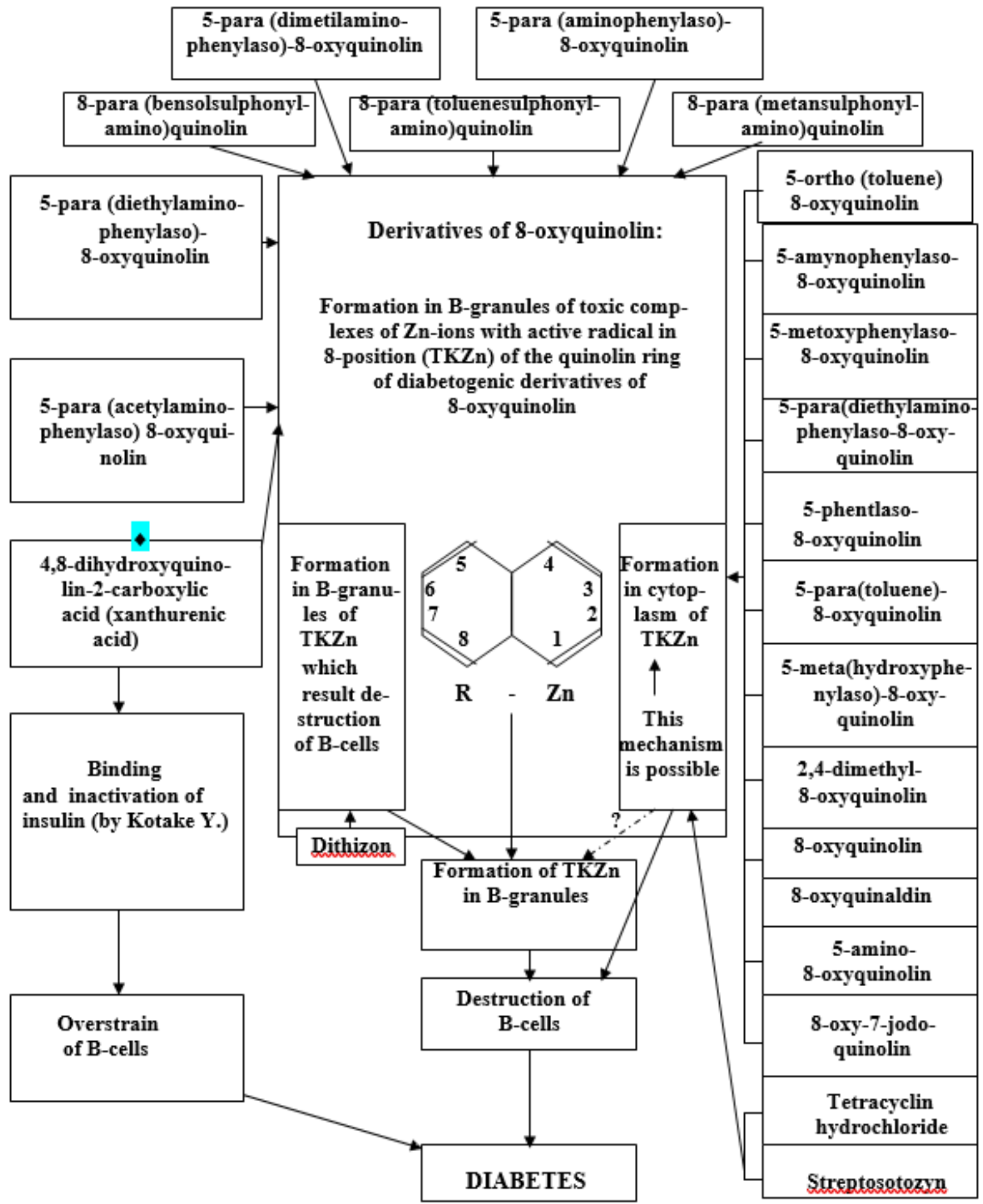

Figure 4. Mechanisms of action of Diabetogenic Chelat Active Chemicals ( - formed in human)

\section{References}

1. Musajo L, Benassi CA (1964) Aspects of disorders of the kynurenine pathway of tryptophan metabolism in man. Adv Clin Chem 7: 63-135. [Crossref]

2. Lepkovsky S, Roboz E, Haagen-Smit AJ (1974) Nutrition classics from The Journal of Biological Chemistry 149:195-201, 1943. Xanthurenic acid and its rõle in the tryptophane metabolism of pyridoxine-deficient rats. Nutr Rev 32: 338-339. [Crossref]

3. Kandori F, Fujinaga Y (1959) Studies of diabetic symptoms caused by xanthurenic acid. Yonaga Acta Med 3: 146
4. Kotake Y (1957) Experiments of chronic diabetic symptoms caused by xanthurenic acid, an abnormal metabolite of tryptophan. Clin Chem 3: 432-446. [Crossref]

5. Kotake Y, Inada T (1954) Effect of xanthurenic acid upon glycogen content in liver, heart and sceletal muscle. J. Biochem 4: 263-266.

6. Kotake Y, Tani S (1953) Studies of xanthurenic acid: xanthurenic acid in the urine of diabetic patients. J. Biochem 3: 295-298.

7. Kuno S (1960) Diabetic changes of pancreas in rats caused by deficiency of vitamin B6. Vitamins 8: 140-154. 
8. Takaoka Y, Yamagushi N (1967) Studies of diabetic activity of xanthurenic acid. $J$. Sashinigaku 7: 19-25.

9. Kotake Y, Inada T (1953) Studies of xanthurenic acid. Preliminary report on xanthurenic acid diabetes. J. Biochem 3: 291-294

10. Kotake Y, Nogami K (1954) Studies of xanthurenic acid. IX. On the conjugated compounds of Xanthurenic acid in the body. J. Biochem 41: 621-625.

11. Ueda T, Goda K, Mori T, Murakami E, Kotake Y (1977) Interaction between xanthurenic acid-insulin complex and zinc ions. J. Biochem 82: 67-72. [Crossref]

12. Ikeda S, Kotake Y (1984) Urinary excretion of xanthurenic acid and zinc in diabetes: 1) Separation of xanthurenic acid- $\mathrm{Zn}^{2+}$ complex by ion-exchange chromatography. Acta Vitaminol Enzymol 6: 23-28. [Crossref]

13. Kotake Y, Kato T (1956) Inhibitory action of etheral sulfate of xanthurenic acid and kynurenic acid with regard to its diabetogenic property proc. Jap Acad 32: 361-363.

14. Weitzel G, Buddecke E, Strecker FJ, Roester U (1954) Zinc binding capacity and glycemic effect of xanthurenic acid kynurenine and tryptophan. Hoppe Seylers $Z$ Physiol Chem 298: 169-184. [Crossref]

15. Kotake Y, Murakami E (1971) A possible diabetogenic role for tryptophan metabolites and effects of xanthurenic acid on insulin. Am J Clin Nutr 24: 826-829. [Crossref]

16. Murakami E (1964) Effect of xanthurenic acid on the photooxidation of insulin by methylene blue. Seikagaku 36: 829-835. [Crossref]

17. Kotake Y, Sotokawa T, Murakami E, Hisatake A, Abe M(1968) Studies on the xanthurenic acid-insulin complex II Physiological activities. J Biochem 63: 578-581. [Crossref]

18. Murakami E (1972) Studies on the xanthurenic acid-insulin complex. J.Biochem 72: 251-259

19. Kotake Y, Ueda T, Mori T, Isaki S, Hattori M (1975) Abnormal tryptophan metabolism and experimental diabetes by xanthurenic acid. Acta Vitaminol Enzymol 29: 236-239.
20. Meyramov GG, Coll (1997) Studies of diabetes action of xanthrenic acid. Bulletin Exper Biol \& Med. Moskva 6: 669-672

21. Meyramov GG, Korchin VI (1998) Does diabetogenic activity of xanthurenic acid determined by its chelating properties? Transplantation Proceedings 30: 2682-2684.

22. Meyramov GG, Coll (2000) Studies of effect of xanthurenic acid on pancreatic islets Acta Diabetologica 37: 160

23. Meyramov GG, Kohnert KD, Meyramova AG, Coll (2001) On the diabetogenic activity of xanthurenic acid. Problemi endocrinologii Moskva 47: 39-44.

24. Meyramov GG, Coll (2003) B6 protect pancreatic b-cells of destruction caused by xanthurenic acid. Diabetes 51: 536.

25. Meyramov GG, Coll (2000) Studies of the Mechanisms of diabetogenic action of xanthurenic acid. Diabetes Res and Clinical Practice 50: 154-155

26. Meyramov GG, Coll (2013) Effects of xanthurenic acid on content of $\mathrm{Zn}^{+2}$ ions in Pancreatic B-cells. Diabetes 61: 719 .

27. Meyramov GG, Coll (2013) Vascular and histological changes in pancreatic islets in diabetes caused by xanthurenic acid. Diabetes 62: 751 .

28. Meyramov GG, Meyramova-Abdraimova AG, Coll (2016) Diabetogenic metabolits of tryptophan. Bulletin of Karaganda State university (biology medicine) 4: 45-56.

29. Meyramova AG (2003) Diabetogenic zinc binding B-cytotoxic Chemicals. Problem endocrinologii.Moskva 49: 8-16.

30. Meyramov GG (2014) Concentration of complex $\mathrm{Zn}^{+2}$-chelator around blood vessels in pancreatic islets result alteration and destruction of capillaries. Bulletin of Karaganda State University (biology, medicine) 4: 96-101.

31. Meyramov GG, Coll (2015) Histological changes in pancreatic islets of animals with experimental diabetes caused by xanthurenic acid under condition of sup- ression of its endogenous synthesis. Bulletin Exper. Biol.\& Med., Moskva 159: 680-684.

Copyright: $\mathbb{C} 2018$ Meyramov GG. This is an open-access article distributed under the terms of the Creative Commons Attribution License, which permits unrestricted use, distribution, and reproduction in any medium, provided the original author and source are credited. 